\title{
Motivators for Demotivators Affecting EFL Learners in Chinese Secondary Vocational School
}

\author{
Chang Liu ${ }^{1}$ \\ ${ }^{1}$ Department of English, City University of Hong Kong, Hong Kong, China \\ Correspondence: Chang Liu, Department of English, City University of Hong Kong, Hong Kong, China
}

Received: February 21, 2020

Accepted: March 19, 2020

Online Published: March 20, 2020

doi: $10.5539 /$ elt.v13n4p41

URL: https://doi.org/10.5539/elt.v13n4p41

\begin{abstract}
The study investigated secondary vocational school students' motivational level to learn English and the demotivating factors perceived by them in the current school stage. To this end, questionnaires were administered to students in a national key secondary vocational school located in Shanxi, China and 62 valid questionnaires were collected. The results revealed that $75.8 \%$ of respondents had already been demotivated in English learning before the secondary vocational school, and the main causes were their dislike of teachers, too much homework and the lack of learning methods. However, there were not so many respondents thinking that they had been further demotivated in learning English in the current vocational school. Concerning the demotivators perceived by participants, the experience of failure was the most dominant whereas the teacher-related factors were the least significant, and the internal factors were more influential than the external ones in impairing participants' learning enthusiasm. New demotivating factors like the perceived increasing roles of Chinese and failing to see the practical significance of English in future jobs and life were also found in this study. Based on the findings of demotivation peculiar to students at secondary vocational schools, the specific motivational strategies were also suggested.
\end{abstract}

Keywords: learning motivation, English as a foreign language, Chinese secondary vocational school, English teachers, learner attitudes

\section{Introduction}

In the study of second language acquisition (SLA), learner's individual difference is one of the focal points, among which motivation has received the most attention (Ellis, 2008). According to Gardner (1985), second language (L2) motivation can be defined as learners' desire or inner strength which pushes them to learn the language and to experience the satisfaction in this process. As the prerequisite for successful English as a second or foreign language (EFL) learning, motivation provides learners with the stimuli to start learning English and a flow of energy to sustain efforts. It is safe to say that all other theories contributing to EFL learning are to some extent based on the premise that the learners are motivated (Dörnyei, 2010). However, inevitably, there are learners whose motivation level is relatively low and students who originally liked learning English have grown to have negative attitudes to English as they proceed in school learning (Hamada, 2011), which call for the research attention to the opposite side of motivation acting in diminishing student's English learning enthusiasm.

Compared with motivation, demotivation is a relatively new research subject and is under-investigated in EFL learning (Boonchuayrod1 \& Getkham, 2019; Chong \& Renandya, 2019; Sakai \& Kikuchi, 2009; Tabatabaei \& Molavi, 2012; Zhang, 2007). It concerns the psychological state of students who were previously motivated to learn English to reach the intended goals, but are now "affected by internal and/or external factors that impede, reduce or even cancel out their learning motivation and restrict their full progress" (Bednáøová, 2012, pp. 29). It can be seen that demotivation may lead to learners' flagging learning momentum, slowing down their English learning process and even dragging them to a complete rejection of English learning. The significance of demotivation in the learning process has prompted many researchers to investigate its impacts, potential causes and how to address these demotivating factors, motivating learners and triggering their learning process afresh (eg, Kikuchi, 2017; Kikuchi, 2019; Song \& Kim, 2017; You, Dörnyei \& Csizér, 2016). Furthermore, the related research has been conducted mostly abroad at university or general secondary school level, and empirical data has rarely been found on the factors that demotivate the particular group of EFL learners who are in a relatively low proficiency level and struggling in English learning because of the weak knowledge foundation, foreign 
language anxiety, lack of learning methods and support, etc. The typical representatives of these EFL learners with learning difficulties are Chinese secondary vocational school students. Due to the paucity of research, English teachers in China secondary vocational schools may fail to have a full picture of whether and why their students are lethargic to English class, and might even miss the point to assist them to be back on track, resulting in the long-term and widespread undesirable learning performance. Therefore, this study attempts to fill this gap by comprehensively investigating the demotivation that Chinese secondary vocational school students could experience in learning English.

\section{Literature Review}

Over the past decade, demotivation has been the interest of both teachers and researchers, due to its great theoretical and practical significance in the English instructional context. Researchers have identified that not only external factors but also internal factors can come into play in demotivating students' English learning (Chong \& Renandya, 2019), which has further expanded Dörnyei's (2001) interpretation of demotivation as the "specific external forces that reduce or diminish the motivational basis of a behavioral intention or an ongoing action" (143). However, Dörnyei was indeed one of the pioneers in the study of language learning demotivation. In his study (1998), 50 Budapest's high school students who were foreign language learners were interviewed to talk about the demotivating factors they had experienced in L2 learning. Consequently, it has been found that factors related to teachers, such as teaching competency, styles and personalities accounted for $40 \%$ of the total, representing the major cause of demotivation perceived by students in language learning. This finding has been echoed by many studies (Chong \& Renandya, 2019; Falout \& Maruyama, 2004; Gorham \& Christophel, 1992; Hasegawa, 2004; Kikuchi, 2009; Kim, 2018; Lamb, 2017; Zhang, 2007), for example, in Zhang's study (2007), undergraduates across four countries were involved and indicated that the most dominant cause of their language learning demotivation was teachers' incompetence, which could be defined as "a cluster of behaviors that reflect teachers' indifference to the students and/or the course" such as "confusing and/or boring lectures, unfair testing and information overload" (Zhang, 2007, pp. 211).

However, though teacher can be a source of demotivation in EFL learning, it is some other studies finding that the intensity of its influence varies with the change of research context. Hamada (2008) surveyed more than 400 Japanese first-year students either in public schools or in universities. He found that the lack of self-confidence was the most significant internal demotivating source, and among all the external factors like teachers, textbooks, nature of English tests and nature of the English language, the last two were the most influential. In another study, Molavi (2012) found that the main demotivating factors for Iranian seminary students were inappropriate teaching methods, the frequency of classes, difficulties in comprehending listening materials and inadequate use of English in real life, among which the first and the most influential one was related to teachers. Besides, based on the study of Sakai and Kikuchi (2009), Krishnan and Pathan (2013) adopted a mixed-method research to explore the causes of demotivation among 116 first semester undergraduates. The results revealed seven demotivators, including (1) grammar-based teaching, (2) teacher's behaviour, (3) course contents and teaching materials, (4) effects of low test scores, (5) classroom environment, (6) lack of self-confidence, (7) a negative attitude towards the English community, among which teaching method, lack of facilities and course content were the dominant factors.

It can be seen that previous research has informed us a variety of external or internal factors which demotivate students in English learning, and we can basically categorize them into the following which are to be adopted in this study: teacher-based factors; learning environment; experience of failure; lack of intrinsic interest; learning contents and materials; negative attitude towards the target language community (Alavinia \& Sehat, 2012; Ghadirzadeh, 2012; Hamada, 2008; Kaivanpanah \& Ghasemi, 2011; Khouya, 2018; Piyaporn \& Kanyarat, 2019; Rastegar, Akbarzadeh \& Heidari, 2012; Zhang, 2007).

Despite a rich number of studies in the field of demotivation perceived by EFL learners, there is a paucity of literature focusing on English learners from the secondary vocational school. Soviana (2018), aiming to investigate the case in Malang, Indonesia, has involved 19 students in her study, and both questionnaires and interviews were administered. The findings showed that the subject experienced both internal and external demotivation, and external factors were more influential than internal ones. External demotivation could be mainly divided into four categories, including teacher's behaviour and competence, teacher's teaching method, learning environment, and the materials of English lesson; whereas internal one fell into three, namely students' attitude toward English, students' experience of failure, and students' self-esteem. Though her study was based on the context of vocational school, the sample size was limited and thus its findings may be hard to be generalized. 
Furthermore, studies on EFL learner's demotivation in China have generally followed the theory and methods of foreign research, and the area of secondary vocational school in China is far less investigated and thus extremely needs to be explored urgently. Li's (2004) experiments on 120 non-English major undergraduate students showed that the demotivating factors related to teachers accounted for $40 \%$ of the total; the empirical study conducted by Li (2013) on the internal causes of demotivation perceived by college English learners concluded that decreased self-confidence, lack of emotional cognitive ability and lack of learning strategies were the three major factors. With the use of questionnaires and interviews among non-English major college students, Zhou and Wang (2012) found from the collected data that of all the factors inducing demotivation in English learning, those related with teachers only accounted for $23.8 \%$, which was much lower than the finding of foreign studies, yet the internal factors accounted for $42.5 \%$. This study reflected that Chinese students to a certain extent tended to attribute their English learning demotivation to themselves.

From the above literature, it can be seen that the empirical research on Chinese English learners' demotivation tends to take university students as research subjects, rarely focusing on secondary vocational school students whose English learning is characterized by low proficiency, exam-oriented and the lack of effective learning strategies and good habits. As Sakai and Kikuchi (2009, pp. 199) suggest, "research on demotivation needs to involve a variety of learners in terms of motivational states and proficiency in English". This is extremely the case for English learners in Chinese secondary vocational schools, whose English learning motivational and proficiency levels are relatively low. It is believed that the comprehensive investigation into it can provide EFL teachers with a new angle to explore the causes of students' underachievement in English learning, thus taking corresponding measures to stimulate their learning enthusiasm and enhance English teachers' teaching efficiency as well.

Therefore, this research attempts to address the literature gap by focusing on the Chinese secondary vocational school setting. Questionnaires were administered to address the following research questions:

(1) Whether Chinese secondary vocational school students were demotivated in English learning before entering the vocational school? When did they experience the demotivation and why?

(2) Are they demotivated in English learning at the current vocational school stage?

(3) What are the main factors that demotivate them to learn English at the secondary vocational school?

\section{Method}

\subsection{Setting and Participants}

This study was conducted in a secondary vocational school in Taiyuan, Shanxi province in mainland China. Being a national key secondary vocational school and national advanced vocational guidance school, the investigated school can to some extent represent the case of secondary vocational schools nationwide. The non-probability, convenience sampling was adopted by the current study since thereby the researcher can approach the subjects as much as possible, getting rich data to address the research questions. Participants were 68 students majoring in Hairdressing and image design, Beauty care and Western Food Service at this school, aged from 16 to 18. In the light of their average English scores for admission and their learning performance in English class, they were considered as being low in English learning proficiency. Specifically speaking, the criteria for choosing these low achievers were as follows. First, students' scores in two formal examinations (mid-term examination and final examination) were referred to (Yao, 2018), those who failed either of the two examinations were selected. Second, English teachers' comprehensive evaluation of students' academic record and study habits were taken. To ensure the reliability of students' responses to questions, the anonymous survey was conducted and students were assured that their answers had nothing to do with their marks for school course. Besides, they were just informed that the researcher was researching on students' motivation in English learning, without knowing the detail of the whole study.

\subsection{Demotivating Questionnaires}

The questionnaire of the current study was developed from the questionnaire administered by Sakai and Kikuchi (2009). Using the questionnaire proven to be effective in the previous studies was advantageous for comparing the results drawn by other studies, seeing whether there are differences in L2 demotivation among students attending different types of high schools or from different national backgrounds. The questionnaire was administered in the Chinese version due to students' limited English literacy levels. It was composed of 36 items which fell into three sections. Section one included 3 items dealing with students' experience of demotivation before the secondary vocational school. Section Two included 30 5-point Likert type questions about their demotivation in English learning at the current high school stage, specifically speaking, whether they were 
demotivated (induced by items 1,2) and the main factors causing the demotivation (items 3-30). Based on the previous studies and researcher's preliminary investigation, six factors were measured: teachers (items $3,9,14$, 17, 19, 21, 23, 24 ), classroom learning environment (items 5, 11, 22, 28), experiences of failure (items 7, 13, 27, 30), attitudes towards the English-speaking community and the practical importance of English (items 8, 20, 26, 29), learning contents and materials (items $4,10,15,18$ ), and lack of intrinsic interest (items $6,12,16,25$ ). In this section, participants were supposed to choose one of the alternatives: 1 . Not true; 2 . To some extent not true; 3. Not clear; 4.To some extent true; and 5.True according to the extent to which the statement of items was true for him or her. Section Three included three open-ended questions to induce students' detailed statement of demotivators they have found in English learning and their expectation of English teachers. Data collected from Section Three can serve as triangulation to confirm participants' responses to 5-point Likert type questions, and also provide in-depth data for us to analyze the causes of demotivation and measures to motivate and improve students' English learning.

\subsection{Analysis}

68 questionnaires were gathered in this survey but with 6 invalid. As this study was primarily descriptive, the quantitative statistical procedures were recommended so that the collected questionnaires were analyzed quantitatively by SPSS version 17.0, which can provide the statistical techniques for giving answers to the RQs.

\section{Results and Discussion}

\subsection{Students' Demotivation in English Learning before the Secondary Vocational School}

First of all, the questionnaire with 30 items showed an internal consistency of 0.777 based on Cronbach's coefficient alpha, which meant that this instrument was valid and the survey results were reliable.

The first research question, whether Chinese secondary vocational school students were demotivated in English learning before entering the vocational school and when did this happen, can be addressed by analyzing the data obtained from the three questions asked in Section One. The results showed that 47 respondents, which meant a great number $(75.8 \%)$ of 62 participants were demotivated in English learning prior to the secondary vocational school. Among these 47 students, 30 students, accounting for $63.83 \%$, claimed that they experienced demotivation at junior school, and $6(12.77 \%)$ students stated that they experienced it at primary school, and $23.40 \%$ believed it occurred at both stages. This meant that the overwhelming majority of investigated students came to the current secondary vocational school with various disappointing experiences related to English learning. Besides, according to these 47 students' response to the third question in Section One, $29.79 \%$ believed teachers should be responsible for their reducing learning enthusiasm, whereas $42.55 \%$ were demotivated due to the examination failure, and $27.66 \%$ identified the exam-oriented learning styles as the main cause of demotivation. Surprisingly, no student thought their parents were the major demotivating factor for their English learning.

Therefore, with regard to the first question, the conclusion can be drawn that a majority of (75.8\%) surveyed students had already been demotivated in English learning before they entered the current secondary vocational school, and the main factors inducing such demotivation were mostly related to their attitudes towards examination and teachers. Knowing that most vocational school students' English learning enthusiasm was relatively low and their learning confidence had already been hurt before they entered the current school, the vocational school English teachers should be more cautious in teaching, lowering their expectation towards students' English competency level and starting teaching from reshaping students' negative learning attitudes.

\subsection{Demotivation in English Learning for Chinese Secondary Vocational School Students}

Concerning the second research question, whether students have experienced the decline in English learning motivation at the current secondary vocational school stage, we can answer it by judging the degree to which the statement of question items 1 and 2 in Section Two was true for students. As the descriptive statistics for both items (Table 1) shows, the means were lower than 3.00 for both item 1 ("I think my English learning enthusiasm has declined since I entered the current vocational school") and item 2 ("I have done things unrelated to English learning in English class more often than before since I entered the secondary vocational school"), and no more than half participants chose 4 (To some extent true) or 5 (True) for both items. Therefore, it is safe to conclude that not so many surveyed students thought they were further demotivated in learning English in the secondary vocational school, especially compared with the case of being demotivated prior to the current school stage. This finding is quite different from the finding from other studies which also investigated the English learning demotivation perceived by Chinese students receiving vocational education (Wang, 2019; Zhang \& Zhang, 2012). According to Wang (2019), the majority of the participants, who were all military cadets thought they 
experienced demotivation in English learning in the current military school, so that the overall circumstance of demotivation for the respondents was strong. This difference may arise since the targeted secondary vocational school students, as mentioned before, have already been demotivated in English learning at primary and junior school. As their motivational baseline is quite low, they may be less likely to be further frustrated at the current secondary vocational school, which compared with the junior school stage when English is a major compulsory subject, does not push students too far if English is concerned.

Table 1. Descriptive statistics for Chinese secondary vocational school students' questionnaire responses $(\mathrm{N}=$ 62)

\begin{tabular}{cccccccc}
\hline No & M & SD & $1(\%)$ & $2(\%)$ & $3(\%)$ & $4(\%)$ & $5(\%)$ \\
\hline 1 & 2.89 & 1.269 & 11 & 32 & 23 & 18 & 16 \\
2 & 2.66 & 1.227 & 24 & 18 & 32 & 19 & 7 \\
\hline
\end{tabular}

Table 2. Descriptive statistics for Chinese secondary vocational school students' questionnaire responses $(\mathrm{N}=$ 62)

\begin{tabular}{|c|c|c|c|c|c|c|c|}
\hline Item & $\mathrm{M}$ & SD & $1(\%)$ & $2(\%)$ & $3(\%)$ & $4(\%)$ & $5(\%)$ \\
\hline 3 & 1.84 & 1.027 & 49 & 26 & 16 & 7 & 2 \\
\hline 4 & 2.90 & 1.169 & 13 & 27 & 23 & 31 & 6 \\
\hline 5 & 2.69 & 1.110 & 16 & 28 & 32 & 19 & 5 \\
\hline 6 & 2.98 & 1.324 & 20 & 10 & 34 & 21 & 15 \\
\hline 7 & 2.89 & 1.344 & 19 & 26 & 13 & 31 & 11 \\
\hline 8 & 1.89 & 1.132 & 52 & 21 & 19 & 3 & 5 \\
\hline 9 & 2.34 & 1.039 & 24 & 32 & 32 & 8 & 4 \\
\hline 10 & 3.23 & 1.298 & 15 & 13 & 26 & 28 & 18 \\
\hline 11 & 2.18 & 1.222 & 37 & 29 & 21 & 5 & 8 \\
\hline 12 & 2.74 & 1.448 & 25 & 24 & 18 & 15 & 18 \\
\hline 13 & 3.10 & 1.289 & 16 & 13 & 32 & 23 & 16 \\
\hline 14 & 1.44 & 0.738 & 66 & 27 & 5 & 0 & 2 \\
\hline 15 & 2.97 & 1.305 & 16 & 22 & 24 & 23 & 15 \\
\hline 16 & 2.82 & 1.337 & 19 & 25 & 23 & 18 & 15 \\
\hline 17 & 2.39 & 1.092 & 22 & 37 & 23 & 15 & 3 \\
\hline 18 & 2.50 & 1.156 & 19 & 37 & 26 & 10 & 8 \\
\hline 19 & 1.66 & 0.829 & 52 & 35 & 8 & 5 & 0 \\
\hline 20 & 2.40 & 1.260 & 34 & 18 & 29 & 13 & 6 \\
\hline 21 & 2.37 & 1.244 & 32 & 26 & 19 & 18 & 5 \\
\hline 22 & 2.05 & 1.108 & 40 & 30 & 15 & 13 & 2 \\
\hline 23 & 1.74 & 0.991 & 53 & 29 & 10 & 6 & 2 \\
\hline 24 & 2.19 & 1.084 & 29 & 37 & 26 & 2 & 6 \\
\hline 25 & 2.10 & 0.936 & 32 & 32 & 29 & 6 & 1 \\
\hline 26 & 2.02 & 1.123 & 42 & 29 & 19 & 5 & 5 \\
\hline 27 & 3.37 & 1.405 & 16 & 13 & 13 & 34 & 24 \\
\hline 28 & 3.37 & 1.517 & 19 & 10 & 19 & 18 & 34 \\
\hline 29 & 3.03 & 1.459 & 19 & 21 & 21 & 15 & 24 \\
\hline 30 & 3.39 & 1.550 & 19 & 13 & 13 & 19 & 36 \\
\hline
\end{tabular}




\subsection{Demotivating Factors in English Learning for Chinese Secondary Vocational School Students}

The reliability of items 3-30, which concern about the factors demotivating students' English learning, was 0.767 .

According to the descriptive statistics for each item (Table 2), we can see the mean scores of items 10, 13, 27, 28, 29,30 are obviously above the average of the mean scores of items 3-30 (2.52), ranging from 3.03 to 3.39 . It means these items can be regarded as sources of demotivation. Meanwhile, items 3, 8, 14, 19, 23 scored far below the average, ranging from 1.44 to 1.89 , reflecting that participants believed these factors had little impact in impairing their English learning willingness. Besides, it is obvious that the means of item 30 ("I had difficulty in memorizing phrases and vocabularies") was 3.39, and both item 27 ("I got low scores on tests (such as mid-term and final examinations)") and item 28 ("Language learning equipment was not provided") were at 3.37, being the first and second highest among all. Thus it is safe to say that they were the strongest demotivators for participants. The item 10 ("English sentences dealt with in the lessons were difficult to interpret") took the fourth place, with a mean score of 3.23. In addition, more participants chose 4 (To some extent true) or 5 (True) in response to the items 4 and 7, namely "Most of the English passage in textbooks focused on the grammars" and "I have spent much time in learning English with little effect". They altogether revealed that there were some common reasons for demotivation perceived by respondents in English learning. Besides, we can also identify some factors which did little impact on impairing participants' English learning motivation. According to Table 2, no more than $10 \%$ participants chose 4 (to some extent true) or 5 (True) in response to the items $3,8,14,19,23$, $24,25,26$, indicating that the factors these items represented could hardly be regarded as English learning demotivators for secondary vocational school students.

\subsubsection{The Interplay of Internal and External Factors}

After the preliminary data analysis, to gain a full picture of the investigated issues and identify the most dominant factors leading to participants' English learning demotivation, a principal axis factor analysis with the method of direct oblimin rotation was performed on the 28 questionnaire items, thereby six factors were extracted. Since there were only 25 items in the questionnaire containing factor loading of more than .40 , the items with lower factor loading, namely items 3, 14, 23 were removed. According to Table 3, the eigenvalues for all six factors were above 1.000 , and the cumulative variance of these six factors accounted for $54.368 \%$ of the total, which could interpret well all the variance and represent a high construct validity. Moreover, in analyzing the factors, we grouped each of the remaining 25 items based on its highest loading. Then, types of demotivation were labeled according to the meaning of items within each type. Thereby, six factors which demotivated English language learning for secondary vocational school students were identified: (1) learning contents and materials, (2) classroom learning environment, (3) teachers' competency and teaching style, (4) experience of failure, (5) attitudes towards the English-speaking community and the practical importance of English and (6) lack of intrinsic interest.

Table 3. Total Variance Explained

\begin{tabular}{cccc}
\hline Factors & Eigenvalue & Variance $\%$ & Cumulative Variance \% \\
\hline 1 & 4.667 & 16.669 & 16.669 \\
2 & 2.721 & 9.717 & 26.386 \\
3 & 2.288 & 8.173 & 34.559 \\
4 & 2.018 & 7.206 & 41.765 \\
5 & 1.912 & 6.828 & 48.592 \\
6 & 1.617 & 5.775 & 54.368
\end{tabular}

The first factor was about learning content and materials like boring passages in the textbook and too much homework. Items fell into the second category, represented by noisy classes, big class capacity and learning equipment, were concerned with the environment of English class, thus we labeled the second factor as the classroom learning environment. The third factor consisted of five items, all of which focused on teachers' teaching competency, like the adequacy of explanation, the way of instruction, and the pace of teaching. The fourth factor was defined by four items related to students' experience of failure, like failing to get ideal scores in tests and making great efforts yet was fruitless. Thus, this factor was named as the experience of failure. The fifth factor was attitudes towards the English-speaking community and the practical importance of English because the items concerning students' impression on English-speaking countries (item 8) and their perception of the practical importance of English (items 20, 26 and 29) loaded on this factor. The sixth, namely the last factor, 
consisting of four items, was labeled as the lack of intrinsic motivation. Therefore, all the main factors which decreased secondary vocational school students' English learning enthusiasm can be concluded, including teachers' competence and teaching styles, learning content and materials, classroom learning environment, the experience of failure, attitudes towards English-speaking community and practical importance of English, and lack of intrinsic motivation.

To further examine the six extracted factors, we divided them into two broad categories, the external factors (factors 1, 2, 3) and the internal factors (factors 4, 5, 6). According to Table 4, we can see the top three demotivators with higher mean values were the experience of failure, learning content and material and lack of intrinsic interest, two of which were internal. However, what was surprising was that the mean score of factor 3 , which was externally about teachers' competence and teaching styles, was the lowest $(M=2.19)$ among the six factors. Based on this result, we can conclude that for the overall investigated secondary vocational school students, they didn't perceive their English teachers as sources of demotivation. Besides, with regard to the interplay of external and internal factors in lowering respondents' English learning enthusiasm, the internal demotivators were more influential than external ones for EFL learners in Chinese secondary vocational school.

\subsubsection{Factors Peculiar to Chinese EFL Learners in Secondary Vocational School}

It has been found in the current study that the major demotivators perceived by Chinese English learners in secondary vocational school are quite different from the findings of other studies in the same field. On the one hand, it is most previous studies' (e.g, Chong \& Renandya, 2019; Dornyei, 2001; Falout \& Maruyama, 2004; Hasegawa, 2004; Kikuchi, 2009; Kim, 2018; Lamb, 2017; Zhang, 2007) finding that teacher-related factors were one of the most influential demotivators among EFL learners, whereas in the current study, when secondary vocational school students were concerned, the finding was exactly the opposite, showing that students thought their teachers exerted the slightest influence on lowering their English learning motivation. We may find the reason for it from students' responses to the open-ended question which induces their elaboration on the demotivators perceived in the process of English learning after entering the secondary vocational school. Some students thought the teacher could not manage the class well because when students kept on talking while the teacher was instructing, the teacher neither stopped them nor took effective measures to avoid the disturbance from happening again, and some students also said they wanted teachers to be more strict in pushing them to learn, not to be loose in controlling students or even indifference to their learning. Teachers' inadequacy as a class manager and students' supervisor being a source of demotivation has also been substantiated by Soviana (2018). However, in the current study, the capability of disciplining students was not included in teachers' overall competence and surveyed in the questionnaire, which may partly account for the result that teachers' competence and teaching styles not being an affecting demotivator. However, the effect of this probable reason was minor, that is to say, we still believed that what the surveyed result signified was that English teachers at the investigated vocational school were basically favored by their students and not being regarded as a demotivating factor for their English learning.

On the other hand, this study found some new factors which may lead to participants' reluctance in learning English. It is worth mention that as the survey results show, a comparatively high percent of (36\%) students thought English may be of little use in their real life, believing that Chinese alone can meet their language need on the job. As we all know, with the increasing prominence of China in the international arena, more and more students come to believe that Chinese would take greater roles and be enough for communication in future life and job. This is especially the case for vocational school students, who are trained to be technicians or servers in certain fields like catering and cosmic and believe that working in the Chinese domestic environment, they may have little chance of using a foreign language as they've mentioned in the open-ended questions. Therefore, students' attitudes towards the practical significance of English especially when it is concerned in relation to Chinese could also be one source of demotivation.

However, similar to the results drawn from the study of Sakai and Kikuchi's (2009) and Zhang and Zhang (2012), the current study has found that the experience of failure has been the most strongly demotivating factor for English learners from secondary vocational school. We can learn from it that when considering why vocational school students' are demotivated in learning English, we should put the internal factors at priority. Specifically speaking, students' frustrating learning experience, lack of learning confidence and interest in or purpose of learning should first be taken into account. For a great number of secondary vocational school students, English learning had already been tricky for them at junior school, and according to the above analysis, most respondents had experienced demotivation before entered the secondary vocational school. Besides, compared with their counterparts at senior high school, secondary vocational school students' English foundation is poor, thus it is more likely for them to have problems in learning English grammar, passages or other contents at the current 
school stage, which explains why they thought learning contents were much too complicated in this study.

Table 4. Factor analysis of demotivation (25-Items)

\begin{tabular}{|c|c|c|}
\hline No. & Items & Loading \\
\hline Factor 1 & Learning Contents and Materials (Mean=2.90) & \\
\hline 4 & Most of the English passage in textbooks focused on grammar. & .718 \\
\hline 10 & English sentences dealt with in the lessons were difficult to interpret. & .527 \\
\hline 15 & The contents we learned in class were boring. & .457 \\
\hline 18 & A great number of textbooks and supplementary readers were assigned. & .722 \\
\hline Factor 2 & Classroom Learning Environment (Mean=2.57) & \\
\hline 5 & Some of my classmates chatted in class, disturbing me from English learning. & .574 \\
\hline 11 & The English class was too crowded. & .626 \\
\hline 22 & Visual materials (such as videos and pictures) were rarely used in class. & .560 \\
\hline 28 & Language learning equipment was not provided. & .532 \\
\hline Factor 3 & Teachers' Competence and Teaching Styles (Mean=2.19) & \\
\hline 9 & Teachers' explanations were not easy to understand. & .570 \\
\hline 17 & Teachers always instructed in a monotonous and boring way. & .575 \\
\hline 19 & Teachers put so much stress on self-learning yet instructed little. & .664 \\
\hline 21 & Teachers failed to design appealing student activities in class. & .657 \\
\hline 24 & The pace of lessons was not appropriate. & .798 \\
\hline Factor 4 & Experiences of Failure (Mean=3.15) & \\
\hline 7 & I have spent much time in learning English with little effect. & .614 \\
\hline 13 & I could not do as well on tests as others no matter how much effort I'd made. & .654 \\
\hline 27 & I got low scores on tests (such as mid-term and final examinations). & .618 \\
\hline 30 & I had difficulty memorizing phrases and vocabulary. & .521 \\
\hline Factor 5 & $\begin{array}{l}\text { Attitudes towards the English-speaking Community and the Practical } \\
\text { Importance of English (Mean=2.36) }\end{array}$ & \\
\hline 8 & $\begin{array}{l}\text { I had a negative impression of English-speaking countries, so I lost my interest } \\
\text { in learning English. }\end{array}$ & .819 \\
\hline 20 & $\begin{array}{l}\text { I believed the role of English in international communication would be } \\
\text { declining. }\end{array}$ & .522 \\
\hline 26 & I thought English was of little use in my life. & .730 \\
\hline 29 & I believed Chinese could meet my future language need on the job. & .751 \\
\hline Factor 6 & Lack of Intrinsic Interest (Mean=2.66) & \\
\hline 6 & I didn't plan to do jobs related to English. & .843 \\
\hline 12 & I was not interested in English culture. & .718 \\
\hline 16 & I lost my understanding of the purpose of studying English. & .516 \\
\hline 25 & I learned English just to pass the exam. & .505 \\
\hline
\end{tabular}

\section{Conclusion and Recommendation}

To investigate the demotivation for Chinese secondary vocational school students in their process of learning English, this study revealed that a majority of respondents had already been demotivated because of their dislike of teachers, too much homework and the lack of learning methods before entered the current secondary vocational school. However, not so many respondents thought they have been further demotivated in learning English since attended the secondary vocational school, which was quite surprising. Concerning the demotivators perceived by students, six factors including teachers' competency and teaching style, learning 
contents and materials, lack of intrinsic interest, classroom learning environment, experience of failure, and attitudes towards the English-speaking community and the practical importance of English were identified, with the experience of failure being the most dominant whereas the teacher-related being the least significant. New factors like the perceived increasing roles of Chinese yet failing to see the practical significance of English in future jobs and life were also found in this study. Besides, the internal factors were more influential than the external ones in impairing participants' learning enthusiasm.

As mentioned above, the school investigated in this study is a national key secondary vocational school where the students come from all over the province, so that it is quite representative. Therefore, in the light of the study findings, EFL teachers in secondary vocational schools should consider the following to enhance students' English learning motivation and overall proficiency:

First, teachers should lower the difficulty of learning content and cultivate students' confidence in learning English. It has been found in this study that many secondary vocational school students with poor academic performance in English often underestimated their learning abilities yet overstated the difficulties they encountered in learning, which indicates that they fail to "conceptualize a positive image of themselves as they strive to achieve their goals" (Kelsen, 2019, pp. 99). Whereas, research in the field of foreign language learning (e.g., Jin \& Dewaele, 2018) has reached a growing consensus that language teachers should encourage and support students to set up positive mindsets and self-image towards language learning, helping them to "develop and maintain their motivation necessary for the long-term undertaking of learning a foreign language" (MacIntyre \& Mercer 2014, pp.156). Therefore, to address this individual issue which we found was peculiar to the EFL learners at secondary vocational schools, teachers should base their teaching on students' learning experience, learning ability, knowledge foundation and future need, and use specific methods like "hope-based interventions, humor and optimism, and realistic goal setting" (Kelsen, 2019, pp. 99) to create more opportunities for students to experience the joy of success in completing the learning tasks.

Besides, teachers are advised to create a non-intimidating and appealing learning atmosphere in class. According to students' expectation towards their current English teachers which they put forward in open-ended questions, they hope teachers can proceed more slowly in class and design more in-class activities and games, present power points which catch students' eyes, converse and interact with students more often and integrate English songs and movies into instruction if appropriate.

In addition, the teaching content should be more practical, oriented to the practical needs posed by students' future job instead of the abstract grammar or other irrelevant knowledge. Since students at secondary vocational schools are mostly trained for certain jobs, if the learning materials can connect with their future professions, their willingness to learn might be stimulated accordingly.

The fourth is that since many learners have regarded the experience of failure like low test scores, unsatisfactory academic performance as demotivating, teachers are advised to guide students to regard the cause of failure reasonably. Though failure itself is frustrating, it gives us a lesson that serves as the ladder to future success. Teachers should assist students in finding their problems in learning, avoiding students from attributing the failure entirely to external factors and regarding it as uncontrollable. They could also lead students to know that the fact of failure can be changed by greater efforts and effective methods.

Lastly, we also found that many respondents didn't get the way to learn English words, phrases and texts, which requires teachers to focus on imparting knowledge and learning strategies as well to improve secondary vocational school students' English competency. Teachers are supposed to inform students of necessary strategies for language learning, including the cognitive strategies (note-taking, translation, reasoning, categorizing and associating), metacognitive strategies (self-assessment, purposeful attention, learning management) and emotional strategies (collaboration, questioning) as well. It is also teachers' responsibility to strengthen the training of these strategies in class, ensuring that students learn to learn.

The major limitation of the study is the range of surveyed schools. Though we focus on the English learners from the particular type of high school, respondents involved were exclusively from one school, thus it may be difficult to generalize our findings to the secondary vocational school students from other contexts like other provinces of China where education is more valued and students are more competitive, let alone other EFL nations. Therefore, future studies that query students' demotivation in learning English at secondary vocational schools are also needed to draw a more general conclusion.

\section{Acknowledgments}

I would like to express my sincere thanks to the teachers in Taiyuan Finance Secondary Vocational School, 
Shanxi Province, China, who have given great support to the current study.

\section{References}

Alavinia, P., \& Sehat, R. (2012). A probe into the main demotivating factors among Iranian EFL learners. English Language Teaching, 5(6), 9-35. https://doi.org/10.5539/elt.v5n6p9

Bednáøová, N. (2012). Demotivating influences for learning English among students on lower stages of 8-year grammar school Unpublished doctoral dissertation. Czech: Masarykova univerzita, Pedagogická fakulta.

Chong, M. Y. C., Renandya, W. A., \& Rong, N.Q. (2019). Demotivation in L2 Classrooms, Teacher and Learner Factors. LEARN Journal, Language Education and Acquisition Research Network, 12(2), 64-75.

Dörnyei, Z. (2001). Teaching and researching motivation. Harlow: Longman. https://doi.org/10.1075/hop.5.mot1

Dörnyei, Z. (1998). Demotivation in foreign language learning. Paper presented at the TESOL ' 98 Congress. Seattle: WA.

Dörnyei, Z. (2010). Researching motivation, From integrativeness to the ideal L2 self. In Hunston, S. \& D. Oakey (Eds.), Introducing applied linguistics, Concepts and skills (pp.74-83). London: Routledge.

Ellis, R. (2008). The study of second language acquisition, 2nd. Oxford: Oxford University Press.

Falout, J., \& Maruyama, M. (2004). A comparative study of proficiency and learner demotivation. The Language Teacher, 28(8), 3-9.

Gardner, R. C. (1985). Social psychology and second language learning: The role of attitudes and motivation. London: Edward Arnold.

Ghadirzadeh, R. (2012). Demotivating factors for English language learning among university students. Journal of Social Sciences, 8(29),189-195. https://doi.org/10.3844/jssp.2012.189.195

Gorham, J. \& Christophel, D. (1992). Students' perception of teacher behaviors as motivating and demotivating factors in college classes. Communication Quarterly, 40(3), 239-252. https://doi.org/10.1080/0146337920

Hamada, Y. (2008). Demotivators for Japanese teenagers. Pan-Pacific Association of Applied Linguistics, 12(2), $1-23$.

Hamada, Y. (2011). Different demotivators for Japanese junior high and high school learners. Journal of Pan-Pacific Association of Applied Linguistics, 15,15-38.

Hasegawa, A. (2004). Student demotivation in the foreign language classroom. Takushoku Language Studies, 107, 119-136.

Jin, Y. X., \& Dewaele, J. M. (2018). The effect of positive orientation and perceived social support on foreign language classroom anxiety. System, 74, 149-157. https://doi.org/10.1016/j.system.2018.01.002

Kaivanpanah, S., \& Ghasemi, Z. (2011). An investigation into sources of demotivation in second language learning. Iranian Journal of Applied Linguistics, 14(2), 89-110.

Kelsen, B. A.(2019). Exploring public speaking anxiety and personal disposition in EFL presentations. Learning and Individual Differences, 73, 92-101. https://doi.org/10.1016/j.lindif.2019.05.003

Khouya, Y. B. (2018). Students demotivating dactors in the EFL classroom, The Case of Morocco. Advances in Language and Literary Studies, 9(2), 150-159. https://doi.org/10.7575/aiac.alls.v.9n.2p.150

Kikuchi, K. (2017). Reexamining demotivators and motivators, A longitudinal study of Japanese freshmen's dynamic system in an EFL context. Innovation in Language Learning and Teaching, 11(2), 128-145. https://doi.org/10.1080/17501229.2015.1076427

Kikuchi, K. (2019). Motivation and demotivation over two years, A case study of English language learners in Japan. Studies in Second Language Learning and Teaching, 9(1), 157-175. https://doi.org/10.14746/ssllt.2019.9.1.7

Krishnan, K. S. D., \& Pathan, Z. H. (2013). Investigating demotivation in learning English, an extension to Sakai and Kikuchi's (2009) framework. Advances in Language and Literary Studies, 4(2), 124-131. https://doi.org/10.7575/aiac.alls.v.4n.2p.124

Kikuchi, K. (2009). Listening to our learners' voice, What demotivates Japanese high school students? Language Teaching Research, 13(4), 453-471. https://doi.org/10.1177/1362168809341520

Kim, T.Y., Kim, Y., \& Kim, J.Y. (2018). A qualitative inquiry on EFL learning demotivation and resilience, A 
study of primary and secondary EFL students in South Korea. Asia-Pacific Education Researcher (Springer Science \& Business Media B.V.), 27(1), 55-64. https://doi.org/10.1007/s40299-017-0365-y

Lamb, M. (2017). The motivational dimension of language teaching. Language Teaching, 50(3), 301-346. https://doi.org/10.1017/S0261444817000088

Li, L. (2013). A study on internal factors of Chinese college EFL learners' Demotivation. Journal of PLA University of Foreign Languages, 36(2), 65-69.

Li, Y. H. (2004). The analysis of EFLlearners'demotivation and promotion of motivation. Dalian Maritime University, China.

MacIntyre, P. D., \& Mercer, S. (2014). Introducing positive psychology to SLA. Studies in Second Language Learning and Teaching, 4(2),153-172. https://doi.org/10.14746/ssllt.2014.4.2.2

Molavi, A. (2012). Demotivating Factors Affecting EFL Learning of Iranian Seminary Students. International Education Studies, 5(1), 181-190. https://doi.org/10.5539/ies.v5n1p181

Piyaporn, B., \& Kanyarat, G. (2019). Investigating EFL achievement through the Lens of demotivation. English Language Teaching, 12(6), 180-190. https://doi.org/10.5539/elt.v12n6p180

Rastegar, M., Akbarzadeh, M., \& Heidari, N. (2012). The darker side of motivation, Demotivation and its relation with two variables of anxiety among Iranian EFL learners. ISRNEducation. https://doi.org/10.5402/2012/215605

Sakai, H., \& Kikuchi, K. (2009). An analysis of demotivators in the EFL classroom. System, 37(1), 57-69. https://doi.org/10.1016/j.system.2008.09.005

Song, B. \& Kim, T. Y. (2017). The dynamics of demotivation and remotivation among Korean high school EFL students. System 65, 90-103. https://doi.org/10.1016/j.system.2016.12.010

Tabatabaei, O. \& Molavi, A. (2012). Demotivating factors affecting EFL learning of Iranian seminary students. International Education Studies, 5(1), 181-190. https://doi.org/10.5539/ies.v5n1p181

Wang X. L. (2019). Research on non-English major military cadets' English learning demotivation and its countermeasures. Journal of Naval university of Engineering, 16(2),74-78.

Yao, Q. L. (2018). An investigation into demotivation of senior high school low achievers in EFL learning. Jiangxi Normal University, China.

You, C., Dörnyei, Z., \& Csizér, K. (2016). Motivation, vision, and gender, A survey of learners of English in China. Language Learning, 66(1), 94-123. https://doi.org/10.1111/lang.12140

Zhang, Q. (2007). Teacher misbehaviors as learning demotivators in college classrooms, a cross-cultural investigation in China, Germany, Japan, and the United States. Communication Education, 56(2), 209-227. https://doi.org/10.1080/03634520601110104

Zhang, X. Q. \& Zhang, J. F. (2012). The study of demotivating factors of English learning in higher vocational colleges. Journal of Hubei Normal University (Philosophy and Social Science), 32(6), 124-127.

Zhou, C. B. \& Wang, W. B. (2012). Demotivators analysis of Chinese university EFL learners. Foreign Languages in China, 9(1), 48-55.

\section{Copyrights}

Copyright for this article is retained by the author(s), with first publication rights granted to the journal.

This is an open-access article distributed under the terms and conditions of the Creative Commons Attribution license (http://creativecommons.org/licenses/by/4.0/). 